\title{
Pathogenicity of acquired immunity in human diseases
}

\author{
Kiyoshi Hirahara ${ }^{1,2}$
}

Received: 15 March 2019 / Accepted: 18 March 2019 / Published online: 3 May 2019

(C) Springer-Verlag GmbH Germany, part of Springer Nature 2019

$\mathrm{CD} 4^{+}$helper $\mathrm{T}$ cells help the function of other immune cells and are thereby critical immune cells for the host defense against infection with harmful microorganisms. Thus, this population plays a central role in adaptive immunity. However, $\mathrm{CD}^{+}$helper $\mathrm{T}$ cells can also be involved in the pathology of various immune-related inflammatory diseases, including allergic diseases and auto-immune diseases [1,2] (Fig. 1). In the classical point of view, helper $\mathrm{T}$ cells were recognized to have two major fates, $\mathrm{T}$ helper 1 (Th1) and Th2 cells, but recent advances in research have revealed opportunities for diverse helper T cell subsets, beyond Th1 and Th2 cells. The new subsets of helper T cells include follicular helper T (Tfh) cells, Th9, Th17, Th22, and different types of regulatory $\mathrm{T}$ cells [3-6].

Among these subsets, Th17 cells produce IL-17A, IL-17F, IL-22, TNF, and GM-CSF and are involved in various types of inflammatory diseases [7]. Yasuda et al. reviewed the molecular basis for Th17 cell differentiation and the effector function in chronic inflammation, especially chronic joint inflammation [8]. They also discussed a pathogenic role of GM-CSF, a key proinflammatory cytokine in autoimmune tissue inflammation [9]. In contrast, regulatory $\mathrm{T}$ (Treg) cells are crucial for maintaining immune homeostasis in vivo [10]. Göschl et al. reviewed the transcription and epigenetic regulation of Treg cells [11]. They also discussed the possibility of Treg cellbased therapies.

In addition to the diversity of $\mathrm{CD} 4^{+} \mathrm{T}$ cell subsets, emerging data indicate that $\mathrm{CD} 4^{+}$helper $\mathrm{T}$ cells show increased plasticity [12]. Functionally, we are beginning to understand the importance of epigenetic regulation such as histone

This article is a contribution to the special issue on The Pathogenicity of Acquired Immunity in Human Diseases - Guest Editor: Kiyoshi Hirahara

Kiyoshi Hirahara

hiraharak@chiba-u.jp

1 Department of Immunology, Graduate School of Medicine, Chiba University, Chiba, Japan

2 AMED-PRIME, AMED, 1-8-1 Inohana, Chuo-ku, Chiba 260-8670, Japan modification and DNA methylation in the appropriate differentiation, activation, and maintenance of helper T cells [13]. Liu et al. reviewed the dysregulation of epigenetic modification in $\mathrm{CD}^{+} \mathrm{T}$ cells, which are closely related to autoimmune diseases [14]. Kurachi et al. also discussed the epigenetic regulation of $\mathrm{T}$ cells, especially $\mathrm{CD} 8^{+} \mathrm{T}$ cells [15].

Rapid technological development allows us to investigate the transcriptional difference at a single-cell level in $\mathrm{CD} 4^{+} \mathrm{T}$ cell populations, revealing the unexpected diversity of various types of immune cells [16]. In the case of Th2 cells, various types of Th2 cells are involved in type 2 immunity-mediated diseases [17-23]. Among these subpopulations, IL-5producing memory Th 2 cells, which are induced by the stimulation with an epithelial cytokine, IL-33, are known to contribute to the pathogenicity of chronic allergic inflammation via the recruitment of eosinophils into the local inflammatory sites in both humans and mice. Thus, this memory Th2 subset was named pathogenic Th2 (Tpath2) cells [19]. Chronic inflammation often causes fibrotic responses in a variety of organs [24]. In the case of the respiratory tract, irreversible asthma is associated with structural alterations of the airway wall such as subepithelial thickening, vascular changes, and fibrosis [25]. An amphiregulin-producing subpopulation of memory Tpath 2 cells, which is distinct from IL-5-producing memory Tpath 2 cells, is critical for shaping the pathology of fibrosis during chronic allergic inflammation [23], [26].

The lung has a unique mucosal barrier system consisting of various types of immune cells which serves to protect the host from the continuous invasion by environmental hazards and pathogens. The migration of $\mathrm{CD} 4^{+} \mathrm{T}$ cells into the inflamed mucosal barrier is a critical step in the pathogenesis of inflammatory diseases. Kimura et al. reviewed the "CD69-Myl9 nets system" that helps antigen-specific Th2 cells infiltrate inflamed tissues [27]. In addition to the lung, the skin protects the host as a mucosal barrier [28]. Sabat et al. reviewed the T cell pathology in immune-mediated skin diseases [29]. The intestine is another major organ that is continuously exposed to extrinsic antigens, such as food [30]. Hagiwara et al. focused on inflammatory bowel diseases (IBDs) and reviewed the epigenetic regulation of helper $\mathrm{T}$ cell differentiation and 
Fig. 1 Two-edged blade of $\mathrm{CD} 4^{+}$ T cells: $\mathrm{CD}^{+}$helper $\mathrm{T}(\mathrm{Th})$ cells protect the host from infection with harmful microorganisms. Th1 cells are crucial for the cellmediated response against intracellular bacteria. Th2 cells mediate the host defense against helminths. Th17 cells contribute to the host defense against extracellular bacteria and fungi.

Regulatory $\mathrm{T}$ (Treg) cells are another $\mathrm{CD}^{+}$subset with essential immunosuppressive functions. However, different pathogenic $\mathrm{T}$ (Tpath) cell subsets are also associated with immune-mediated diseases, including allergic diseases and auto-immune diseases. IBD, Inflammatory bowel disease.

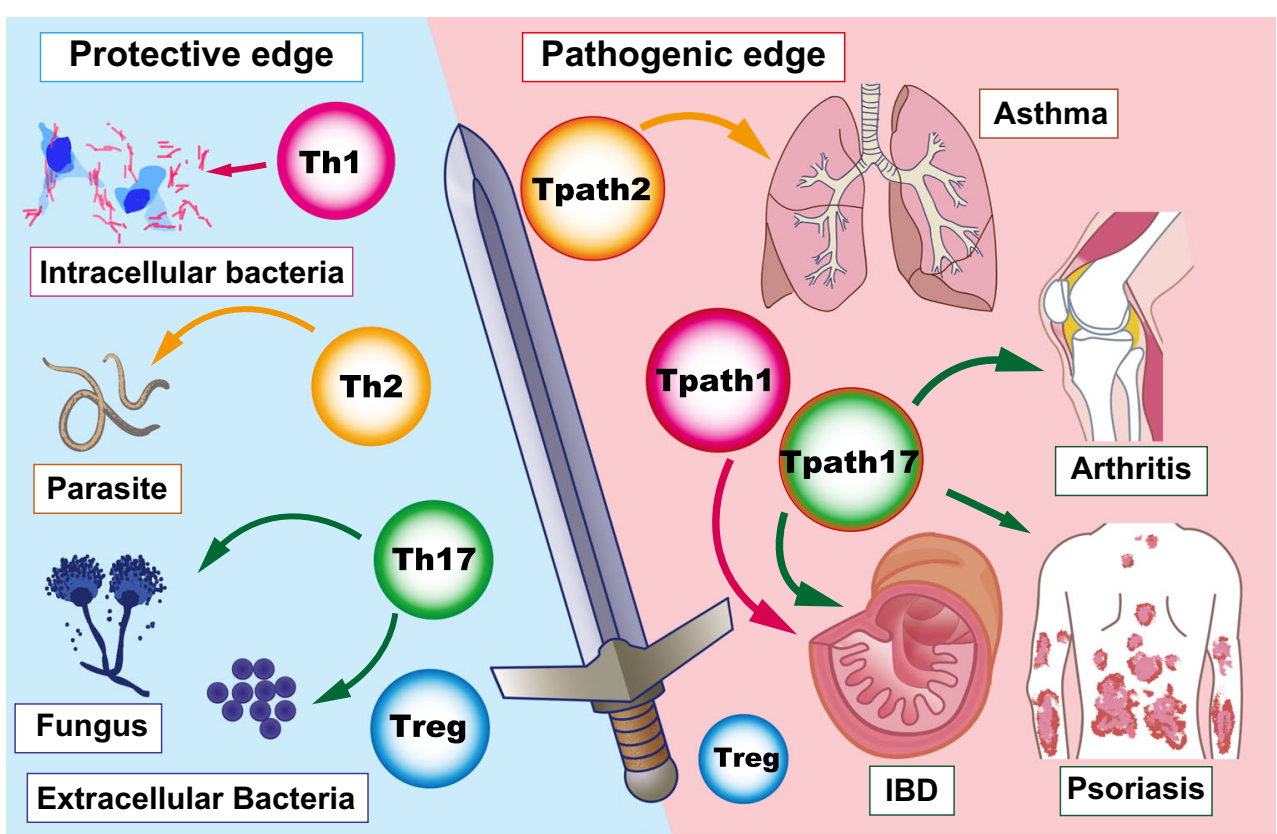

the pathogenic role of $\mathrm{CD}^{+}$helper T cells in chronic intestinal inflammatory diseases [31]. Kwok et al. reviewed the unique roles of invariant natural killer T (iNKT) cells and mucosalassociated invariant $\mathrm{T}$ (MAIT) cells at barrier tissues such as the lung and skin [32].

Fortunately, we are beginning to understand the cellular and molecular basis for the complexity of $\mathrm{T}$ cell pathology and these new insights provide a more sophisticated understanding of immune-mediated disease and new opportunities for therapy.

Acknowledgments The figure was drawn together with Dr. Mikiko Okano of Chiba University.

Funding information This work was supported by the following grants: Ministry of Education, Culture, Sports, Science and Technology (MEXT Japan) Grant-in-Aid for Scientific Research (C) 17K08876; Practical Research Project for Allergic Diseases and Immunology (Research on Allergic Diseases and Immunology) from the Japan Agency for Medical Research and Development, AMED (No. JP18ek0410045); AMED-PRIME, AMED (No. JP18gm6110005); Mochida Memorial Foundation for Medical and Pharmaceutical Research; The Ichiro Kanehara Foundation for the Promotion of Medical Sciences and Medical Care; and Takeda Science Foundation.

\section{Compliance with ethical standards}

Competing interests The author declares that he has no conflict of interest.

\section{References}

1. Nakayama T, Hirahara K, Onodera A, Endo Y, Hosokawa H, Shinoda K, Tumes DJ, Okamoto Y (2017) Th2 cells in health and disease. Annu Rev Immunol 35:53-84
2. Sallusto F (2016) Heterogeneity of human CD4(+) T cells against microbes. Annu Rev Immunol 34:317-334

3. Korn T, Bettelli E, Oukka M, Kuchroo VK (2009) IL-17 and Th17 cells. Annu Rev Immunol 27:485-517

4. Zhu J, Yamane H, Paul WE (2010) Differentiation of effector CD4 T cell populations. Annu Rev Immunol 28:445-489

5. Crotty S (2011) Follicular helper CD4 T cells (TFH). Annu Rev Immunol 29:621-663

6. Panduro M, Benoist C, Mathis D (2016) Tissue Tregs. Annu Rev Immunol 34:609-633

7. Hirota K, Ahlfors H, Duarte JH, Stockinger B (2012) Regulation and function of innate and adaptive interleukin-17-producing cells. EMBO Rep 13(2):113-120

8. Yasuda K, Takeuchi Y, Hirota K (2019) The pathogenicity of Th17 cells in autoimmune diseases. Semin Immunopathol. https://doi. org/10.1007/s00281-019-00733-8

9. Hirota $\mathrm{K}$, Hashimoto $\mathrm{M}$, Ito $\mathrm{Y}$, Matsuura $\mathrm{M}$, Ito $\mathrm{H}$, Tanaka M, Watanabe H, Kondoh G, Tanaka A, Yasuda K, Kopf M, Potocnik AJ, Stockinger B, Sakaguchi N, Sakaguchi S (2018) Autoimmune Th17 cells induced synovial stromal and innate lymphoid cell secretion of the cytokine GM-CSF to initiate and augment autoimmune arthritis. Immunity 48(6):1220-1232 e5

10. Wing JB, Tanaka A, Sakaguchi S (2019) Human FOXP3(+) regulatory $\mathrm{T}$ cell heterogeneity and function in autoimmunity and cancer. Immunity 50(2):302-316

11. Göschl L, Scheinecker C, Bonelli M (2019) Treg cells in autoimmunity: from identification to Treg-based therapies. Semin Immunopathol. https://doi.org/10.1007/s00281-019-00741-8

12. O'Shea JJ, Paul WE (2010) Mechanisms underlying lineage commitment and plasticity of helper CD4+ T cells. Science 327(5969): 1098-1102

13. Schmidl C, Delacher M, Huehn J, Feuerer M (2018) Epigenetic mechanisms regulating T-cell responses. J Allergy Clin Immunol 142(3):728-743

14. Liu H, Li P, Wie Z, Zhang C, Xia M, Du Q, Chen Y, Liu N, Li H, Yang X-P (2019) Regulation of T cell differentiation and function by epigenetic modification enzymes. Semin Immunopathol. https:// doi.org/10.1007/s00281-019-00731-w

15. Kurachi $\mathrm{M}(2019) \mathrm{CD}^{+} \mathrm{T}$ cell exhaustion. Semin Immunopathol. https://doi.org/10.1007/s00281-019-00744-5 
16. Giladi A, Amit I (2018) Single-cell genomics: a stepping stone for future immunology discoveries. Cell 172(1-2):14-21

17. Endo Y, Iwamura C, Kuwahara M, Suzuki A, Sugaya K, Tumes DJ, Tokoyoda K, Hosokawa H, Yamashita M, Nakayama T (2011) Eomesodermin controls interleukin-5 production in memory $\mathrm{T}$ helper 2 cells through inhibition of activity of the transcription factor GATA3. Immunity 35(5):733-745

18. Islam SA, Chang DS, Colvin RA, Byrne MH, McCully ML, Moser B, Lira SA, Charo IF, Luster AD (2011) Mouse CCL8, a CCR8 agonist, promotes atopic dermatitis by recruiting IL-5+ T(H)2 cells. Nat Immunol 12(2):167-177

19. Endo Y, Hirahara K, Iinuma T, Shinoda K, Tumes DJ, Asou HK, Matsugae N, Obata-Ninomiya K, Yamamoto H, Motohashi S, Oboki K, Nakae S, Saito H, Okamoto Y, Nakayama T (2015) The interleukin-33-p38 kinase axis confers memory T helper 2 cell pathogenicity in the airway. Immunity 42(2):294-308

20. Mitson-Salazar A, Yin Y, Wansley DL, Young M, Bolan H, Arceo S, Ho N, Koh C, Milner JD, Stone KD, Wank SA, Prussin C (2016) Hematopoietic prostaglandin D synthase defines a proeosinophilic pathogenic effector human TH2 cell subpopulation with enhanced function. J Allergy Clin Immunol 137(3):907-918 e9

21. Wambre E, Bajzik V, DeLong JH, O'Brien K, Nguyen QA, Speake C, Gersuk VH, DeBerg HA, Whalen E, Ni C, Farrington M, Jeong D, Robinson D, Linsley PS, Vickery BP, Kwok WW (2017) A phenotypically and functionally distinct human $\mathrm{TH} 2$ cell subpopulation is associated with allergic disorders. Sci Transl Med 9(401): eaam9171

22. Mato N, Hirahara K, Ichikawa T, Kumagai J, Nakayama M, Yamasawa H, Bando M, Hagiwara K, Sugiyama Y, Nakayama T (2017) Memory-type ST2+CD4+ T cells participate in the steroidresistant pathology of eosinophilic pneumonia. Sci Rep 7(1):6805

23. Morimoto Y, Hirahara K, Kiuchi M, Wada T, Ichikawa T, Kanno T, Okano M, Kokubo K, Onodera A, Sakurai D, Okamoto Y, Nakayama T (2018) Amphiregulin-producing pathogenic memory T helper-2 cells instruct eosinophils to secrete osteopontin and facilitate airway fibrosis. Immunity In press 49:134-150.e6
24. Gieseck RL 3rd, Wilson MS, Wynn TA (2018) Type 2 immunity in tissue repair and fibrosis. Nat Rev Immunol 18(1):62-76

25. Lambrecht BN, Hammad H (2015) The immunology of asthma. Nat Immunol 16(1):45-56

26. Hirahara K, Aoki A, Morimoto Y, Kiuchi M, Okano M, Nakayama $\mathrm{T}$ (2019) The immunopathology of lung fibrosis: amphiregulinproducing pathogenic memory $\mathrm{T}$ helper- 2 cells control the airway fibrotic responses by inducing eosinophils to secrete osteopontin. Semin Immunopathol. https://doi.org/10.1007/s00281-019-00735-6

27. Kimura MY, Koyama-Nasu R, Yagi R, Nakayama T (2019) A new therapeutic target: the CD69-Myl9 system in immune responses. Semin Immunopathol. https://doi.org/10.1007/s00281-019-00734-7

28. Yazdi AS, Rocken M, Ghoreschi K (2016) Cutaneous immunology: basics and new concepts. Semin Immunopathol 38(1):3-10

29. Sabat R, Wolk K, Loyal L, Döcke WD, Ghoreschi K (2019) T cell pathology in skin inflammation. Semin Immunopathol. https://doi. org/10.1007/s00281-019-00742-7

30. Kanai T, Mikami Y, Hayashi A (2015) A breakthrough in probiotics: Clostridium butyricum regulates gut homeostasis and anti-inflammatory response in inflammatory bowel disease. $\mathrm{J}$ Gastroenterol 50(9):928-939

31. Hagihara Y, Yoshimatsu Y, Mikami Y, Takada Y, Mizuno S, Kanai $\mathrm{T}$ (2019) Epigenetic regulation of T helper cells and intestinal pathogenicity. Semin Immunopathol. https://doi.org/10.1007/s00281019-00732-9

32. Yip KH, Papadopoulos M, Pant H, Tumes DJ (2019) The role of invariant $\mathrm{T}$ cells in inflammation of the skin and airways. Semin Immunopathol. https://doi.org/10.1007/s00281-019-00740-9

Publisher's note Springer Nature remains neutral with regard to jurisdictional claims in published maps and institutional affiliations. 